\title{
Bitter fight over CRISPR patent heats up
}

\section{Unusual battle among academic institutions holds key to gene-editing tool's future use.}

\section{BY HEIDI LEDFORD}

A versatile technique for editing genomes has been called the biggest biotechnology advance since the polymerase chain reaction (PCR), and the US Patent and Trademark Office (USPTO) is set to determine who will reap the rewards.

On 11 January, the USPTO granted a request to review a key patent awarded for the technique, known as CRISPR-Cas9. The outcome of the ensuing proceedings, called a patent interference, could be worth millions to the research institutions that are at war over the relevant patents. It might also influence who is allowed to use the technology - and under what terms.

"This is an absolutely humungous biotech patent dispute," says legal scholar Jacob Sherkow of New York Law School. "We're all waiting with bated breath."

CRISPR-Cas9 is a bacterial defence system that uses the enzyme Cas9 to snip DNA at sites determined by the sequence of a 'guide' strand of RNA. The technology allows scientists to disable, replace or tweak genes by rewriting snippets of DNA sequences. Use of CRISPR-Cas9 in research has exploded, thanks to its relative simplicity and versatility compared to other gene-editing methods. Several companies have sprung up to harness the technique for generating improved crops, research reagents and therapies for human genetic diseases.

The roots of the CRISPR-Cas9 patent fight date back to 2012, when researchers reported that they had reprogrammed the system to cut strands of isolated DNA at sites of their choosing ${ }^{1}$. The team, led by biologists Jennifer Doudna at the University of California, Berkeley, and Emmanuelle Charpentier, now at the Max Planck Institute for Infection Biology in Berlin and Umeå University in Sweden, filed a patent application on 15 March 2013.

By then, publications had emerged from other groups showing that the method works in human cells ${ }^{2-4}-$ bolstering dreams of CRISPR-based gene therapies.

One of those groups, led by synthetic biologist Feng Zhang of the Broad Institute and the Massachusetts Institute of Technology, both in Cambridge, filed a patent application for the CRISPR-Cas9 technique in October 2013.

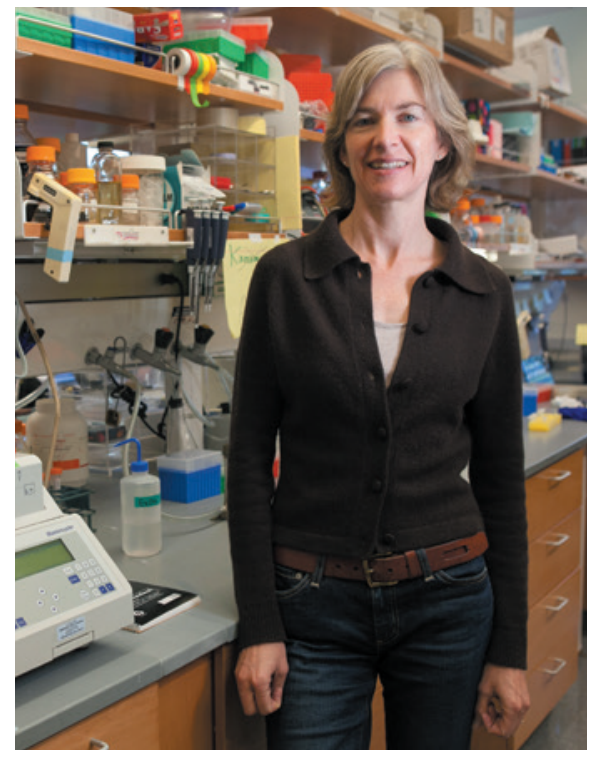

Jennifer Doudna of the University of California, Berkeley, helped to develop the CRISPR system.

The institutions filed the patent under a special expedited review programme, and it was granted in April 2014. Zhang has since been awarded additional patents on the technology. The original Doudna-Charpentier patent remains under review.

\section{A PITCHED BATTLE}

In April 2015, the Berkeley team asked the USPTO to determine which team was the first to invent the technique. Now the patent office has agreed to begin that interference proceeding, which will be much like a court case, with both sides presenting evidence culled from publications and laboratory notebooks. "Once the [USPTO] declares an interference, that's really when the fur is going to fly," Sherkow predicted in a June interview.

The patent interference is also a testament to the high stakes involved: companies aiming to use CRISPR-Cas9 for gene therapy have raised hundreds of millions in venture capital and other funds in less than three years. One company, Editas Medicine in Cambridge, Massachusetts, has already filed to go public.

Arti Rai, a legal scholar at Duke University in Durham, North Carolina, says that it is unusual for academic research institutions to battle so intensely over a patent. Instead, such institutions usually come to an agreement to share rights to the invention. "This seems more bitter than disputes I've heard of in the past," she adds.

The two patents in question make broad claims to 'foundational' intellectual property thought to be necessary for most lucrative CRISPR-Cas9 applications. But many patents have been filed on CRISPR-Cas9 technologies, and there is still the chance that the winner of the interference will face additional challenges in court. Zhang's group has also reported another enzyme, called Cpf1, that functions much like Cas9. Researchers expect other alternatives to emerge with time.

\section{LICENSING LOOMS}

For now, it is unclear how the dispute will affect researchers who use CRISPR-Cas9, if it does so at all. "Patent holders might send out a few cease-and-desist letters, but they probably won't sue academic researchers," says Rodney Sparks, a biotechnology-patent counsel at the University of Virginia in Charlottesville. Doing so would take time and money with little reward: the spoils in a patent lawsuit are typically damages or a share of royalties from a marketed product. That leaves little to gain from suing academics who are not selling anything. But those who intend to use their research as the basis for a start-up company will need to be wary, Sparks says.

Some patent holders do ask that even scientists doing basic research take out a licence on a patented technology, typically for a fairly small fee. Such was the case for PCR, says Warren Woessner, a lawyer at Schwegman, Lundberg and Woessner in Minneapolis, Minnesota. The Broad Institute has noted on its website that it will continue to make CRISPR-Cas9 reagents available to the community, and has given no indication that it will pursue hefty licensing fees from academics. But Sherkow warns against assuming that the spirit of academic camaraderie will always prevail: licensing revenue has become increasingly important, particularly for major research institutions, he says. "We're just living in a brave new world these days." -

\footnotetext{
1. Jinek, M. et al. Science 337, 816-821 (2012).

2. Cong, L. et al. Science 339, 819-823 (2013).

3. Mali, P. et al. Science 339, 823-826 (2013).

4. Jinek, M. et al. eLife 2, e00471 (2013).
} 